\title{
Tlmočenie v štátnej správe: deskriptívne a preskriptívne prístupy ${ }^{1}$
}

\author{
Interpreting in the State Administration: Prescriptive \\ and Descriptive Approaches
}

Helena Tužinská

\begin{abstract}
In cases of interpreting for foreigners in the public sector, there is a need for both intercultural translation and understanding of the language of legislation. Studies on the sociocultural aspects of interpreting focus on the fatal consequences of the unreflected character of various language registers in legal settings (Barsky, 2000; Berk-Seligson, 2002; Eades, 2010; Gibbons, 2003; Good, 2007; Maryns, 2006; Philips, 1998; Wadensjö, 1998). In the literature there is a call for understanding communication as the non-linear interaction of all participants and interpreting as a process of intercultural exchange. The observations of linguistic and legal anthropologists, sociolinguists, interpreters and lawyers in this field point to two underlying tendencies: prescriptive and descriptive. This article links these findings with the author's observations since 2005 and data collected in 2010-2011 by nonprofit organizations providing legal assistance to migrants in Slovakia, Czech Republic, Hungary, Poland and Ukraine, where inadequacies in interpreting and their causes and legal consequences have been identified. In this context, my focus is on the different manifestations of the prescriptive and descriptive approaches in relation to the interactions between applicant, interpreter, decision-maker and observer.
\end{abstract}

KEY WORDS Interpreting, migrants, prescriptive and descriptive approach, linguistic anthropology, sociolinguistics, legal anthropology

\section{Úvod}

Analýza dynamiky tlmočenia v právnom prostredí, v ktorom sa pohybujú aj migranti, je v posledných rokoch predmetom zvýšeného záujmu lingvistických a právnych antropológov, sociolingvistov, tlmočníkov i právnikov (Barsky 2000; Berk-Seligson 2002; Eades 2010; Gibbons 2003; Good 2007; Maryns 2006; Philips 1998; Wadensjö 1998). Tvrdenia odborníkov, ktorí sa pohybujú v prieniku polí jazyka a práva, prepájam s vlastnými zisteniami v špecifickom prostredí štátnej správy a neziskových organizácií poskytujúcich právnu pomoc

Sociální studia. Katedra sociologie FSS MU, 2/2015. S. 51-68. ISSN 1214-813X.

1 Uvedený text je súčast’ou riešenia projektu VEGA č. 1/0035/14, Spoločensko-kultúrna reflexia telesnosti v životnom cykle ženy. 
migrantom. Mojím ciel’om je upriamit' pozornost' na príčiny a dôsledky nereflektovania rôznosti jazykových registrov v právnom prostredí.

Nakol'ko sa na tomto mieste venujem práve tlmočeniu, pre môj argument je dôležité poznamenat', že komunikáciu rozumiem ako komplexnú a nelineárnu interakciu všetkých aktérov. V texte sa zameriavam na spôsoby, akými sa v interakcii žiadatel’a, tlmočníka, rozhodovatel'a a pozorovatel'a prejavujú dva prístupy - preskriptívny a deskriptívny. Deskriptivita sa prepája s d'alšími konceptami, ako sú orientácia na kontext, proces, interakcionistické ponímanie, dialogizmus a orientácia na vzt’ahy. Preskriptivita je previazaná s korešpondujúcimi sklonmi, ako je orientácia na text, zápis, legalistické a mechanické ponímanie, jednosmernost', monologizmus a orientácia na pravidlá. Tieto tendencie sa prejavujú v rôznom pomere v každej situácii, no pre potreby zovšeobecnenia na ne budem odkazovat', aj ked' v „čierno-bielom podani““ sa nezvyknú vyskytovat' a predstavujú tak krajné pozície kontinua praktík.

V štúdii vychádzam z vlastných pozorovaní interakcií žiadatel’ov o azyl, ako aj iných migrantov a pracovníkov štátnej aj neštátnej správy od r. 2005. Povaha môjho výskumu vychádzala $\mathrm{z}$ mojej spolupráce $\mathrm{s}$ neziskovými organizáciami. Etnografické techniky som používala v rámci interview so žiadatel'mi o azyl, aby mali argumentačný podklad pre svojich právnych zástupcov, a počas pozorovaní na súdoch, aby som porozumela priebehu pojednávania a spolupripravila naň žiadatel’ov o azyl. Ako spolulektorka som sa zúčastnila na niektorých vzdelávacích podujatiach či konferenciách pre pracovníkov Hraničnej a cudzineckej polície, Migračného úradu a súdov (Tužinská 2009a, 2009b, 2010, 2015).

V tomto zmysle dáta, ktoré prezentujem, sú vd'aka môjmu pôsobeniu nevyhnutne skreslené. V aktivitách som skôr bola vnímaná ako osoba, ktorá stojí na strane žiadatelov, hoci osobne som $\mathrm{v}$ žiadnom z prípadov intervencie vo veciach žiadatel'ov o azyl neiniciovala. Nakol'ko som ako výskumníčka pôsobila v neziskovej organizácii obhajujúcej práva migrantov, ktorá si kládla za ciel' ich situáciu zlepšit', v tomto texte sa venujem viac pohl'adu žiadatel'ov. Dlhodobý výskum medzi predstavitel'mi štátnych inštitúcií som nevykonala, preto pozíciu rozhodovatel'ov prezentujem len čiastočne. ${ }^{2}$

Kvôli lepšej prehl'adnosti označujem štyri rôzne pozície aktérov: žiadatel', tlmočník, rozhodovatel' a pozorovatel'. Pod pojmom žiadatel' tak rozumiem nielen žiadatel'ov o azyl, ale aj iných cudzincov, od ktorých štátna správa vyžaduje akýkol'vek administratívny úkon. Tlmočníci môžu byt' súdni, ale aj neprísažní, alebo náhodne oslovení. Rozhodovatelia môžu byt' príslušníci Policajného zboru, úradníci, sudcovia a iní, ktorí o žiadatel’och rozhodujú. Pozorovatelia môžu byt' sociálni vedci, alebo iní, ktorí pozorujú.

Štruktúra príspevku zodpovedá mojej argumentačnej línii. Najskôr prezentujem zdroje dát a opisujem východiskovú situáciu žiadatel’ov a ich interakciu s rozhodovatel'mi. V d’al'šej časti, o zodpovednosti a zodpovedatel'nosti, uvádzam komunikačné potreby aktérov a rôznost' deskriptívneho a preskriptívneho prístupu $\mathrm{v}$ jednaní. $\mathrm{V}$ opise procesne a zápisne orientovaných rozhodovatel’ov ukazujem, ako sa prejavujú predovšetkým na súdoch. V predposlednej

2 Som si vedomá etických dilem, ktoré vyplývajú z uvádzania antropologických poznatkov pred inštitúciami. Vynikajúco ich rozpracoval právny antropológ a súdny expert Anthony Good (1997, 2008). 
časti sa venujem ukážkam premeny hovoreného slova na písané slovo, ako aj tvorbe zápisníc. Napokon opisujem situácie, v ktorých dialogické tlmočenie nadväzuje na deskriptívne postupy a ako súvisí preskriptívne konanie a monologické tlmočenie.

\section{Zdroje dát}

Zistenia $\mathrm{z}$ praxe tlmočenia som sumarizovala $\mathrm{v}$ porovnávacej správe, ktorú som zostavila na základe vlastných pozorovaní a národných správ právnikov, ktorí mali skúsenosti $\mathrm{s}$ tlmočením pre cudzincov v správnych orgánoch a na súdoch v krajinách V4 a na Ukrajine (Tužinská 2011b). ${ }^{3}$

Počas výskumu boli sledované tieto oblasti so zásadným vplyvom na kvalitu tlmočenia:

- okolnosti, čas, priestor a kontext rozhovoru

- konanie aktérov: žiadatel' (cudzinec), zastúpenie inštitúcie (príslušník Policajného zboru, úradník, sudca), tlmočník (súdny, neprísažný, náhodný), právnik a pozorovatel'

- ne/prítomnost' a správanie ne/kvalifikovaného tlmočníka

- štandardy tlmočenia $v$ danej inštitúcii

- komunikačné a medzikultúrne zručnosti tlmočníka

- jazykové znalosti právnických výrazov tlmočníka

- právne dôsledky nepresného tlmočenia pre cudzinca a pre tlmočníka

- inštitucionálne praktiky a vplyv vedenia interview na priebeh tlmočenia

Medzi hlavné identifikované nedostatky komunikácie štátnej správy a cudzincov v správnom a súdnom konaní patrili:

- nepresnost' určenia jazykov tlmočenia

- nezrozumitel'nost' úradných postupov

- absencia kvalitatívneho interview so žiadatel'om

- tvorba sumarizujúcich zápisníc

- nedostupnost', nedostatok a neetickost' tlmočenia

- inštitucionálne prekážky kvalifikovaného tlmočenia

Pre komplexnejší pohl'ad vychádzajúci z komparatívnej správy budem uvádzat' tie príklady, ktoré boli popisované vo všetkých sledovaných krajinách a zároveň ktoré sa v rôznych rolách opakovali. Súčast'ou správy bola aj tvorba odporúčaní, ktoré som zostavovala na základe zistení všetkých aktérov. Napriek tomu, ani kritika systému, ani odporúčania nie sú predmetom tohto článku.

3 Porovnávacia štúdia je výstupom projektu „Komunikácia s cudzincami: právne dôsledky tlmočenia. Porovnanie praktík v krajinách V4: v Pol'sku, v Mad’arsku, v Česku, na Slovensku a na Ukrajine“. Autorkami národných správ sú Maja Tobiasz (PL), Orsolya Szántai Vecsera (HU), Hana Franková (CZ), Zuzana Števulová (SK) a Kristina Yarosh (UA). Texty sú prístupné v národných jazykoch a angličtine na stránkach organizácií všetkých účastníkov projektu, ako i online na http:// www.hrl.sk/publikacie a https://uniba.academia.edu/HelenaTužinská. 


\section{Opis interakcií}

Popisované situácie sa odohrávali na štyroch rôznych miestach: (1) na policajných oddeleniach, (2) v zariadeniach pre cudzincov (pre ich záchyt, zaistenie alebo pre pobyt), (3) na úradoch (najmä migračný) a (4) na súdoch (najmä Krajský, príp. Najvyšší). Situácie, v ktorých sa stretávajú žiadatelia s rozhodovatel'mi, spravidla nepatria medzi neutrálne. Migračná politika je v Slovenskej republike reštriktívna a splnit' všetky zákonné podmienky na vstup je náročné.

Najprv stručne zhrniem možné trajektórie žiadatel’ov v SR pri styku s úradmi. Ak cudzinec prekročí štátnu hranicu bez platného cestovného dokladu a/alebo víz a nevie sa preukázat' potrebnou sumou na pokrytie jeho/jej nákladov na pobyt v SR (60 Eur na deň), príslušný policajný útvar ho vyzve na podanie vysvetlenia. V takom prípade má polícia právo vykonat' osobnú prehliadku vrátane batožiny a odňat' cestovný doklad. Príslušník Policajného zboru následne zist'uje dôvod takéhoto prekročenia hranice ako aj totožnost' cudzinca a jeho rodinných príslušníkov, trasu príchodu do SR a dôvody opustenia krajiny pôvodu.

Cudzinec má právo na tlmočenie. $\mathrm{V}$ časovo napätých situáciách, alebo $\mathrm{v}$ prípade potreby tlmočenia do zriedkavejších jazykov, tlmočí niekto zo skupiny cudzincov. V prípade, že zadrží jedno pracovisko väčšiu skupinu cudzincov, je neuskutočnitel'né do 48 hodín (časový limit pre administratívne vyhostenie v prípade neoprávneného vstupu) zohnat' kvalifikovaných tlmočníkov, vykonat' dôkladné interview a zhotovit' zodpovedajúcu zápisnicu.

Ak vyhost'ovanie trvá dlhšie, cudzinec je zaistený v útvare policajného zaistenia pre cudzincov (v Medved’ove alebo Sečovciach), kde je zákaz vychádzania, denný režim a strážené cely. Na druhej strane, ak cudzinec vyhlási, že žiada o udelenie azylu alebo o poskytnutie doplnkovej ochrany, vstup do SR mu nemôže byt' odopretý. Cudzinec sa musí dostavit' na policajné oddelenie azylu pri Záchytnom tábore v Humennom. V pohovore sa zist'ujú dôvody, pre ktoré sa cudzinec nemôže vrátit' do krajiny pôvodu.

Následne príslušník Policajného zboru vyhotoví stručnú zápisnicu o podaní vysvetlenia, kde sú osobné údaje, popis cesty a dôvody žiadosti o azyl ${ }^{4}$, a s cudzincom spíše vyhlásenie o azyle. Potom cudzincovi odníme doklad totožnosti a spolu so žiadost’ou o azyl a zápisnicou ho pošle na Migračný úrad Ministerstva vnútra SR, ktorý bude rozhodovat' o udelení/ neudelení medzinárodnej ochrany spravidla ešte po d’alších interview a overovaní údajov. Príslušník Policajného zboru tiež odníme odtlačky prstov a zadá ich do Európskeho systému evidencie cudzincov.

Zároveň, ak cudzinec už predtým prekročil neoprávnene hranice v inom štáte Európskej únie, čo dosvedčia odtlačky, bude vrátený na územie toho štátu. Inak je po troch týždňoch pobytu $\mathrm{v}$ záchytnom tábore umiestnený do pobytového tábora. $\mathrm{V}$ prípade, že jeho žiadost' o azyl bola zamietnutá, alebo bol neoprávnene zaistený, má možnost' sa odvolat', súd ho môže predvolat' a vypočúvat', a následne rozhodne o potvrdení alebo o zrušení rozhodnutia

$4 \quad$ Azyl je poskytnutý osobám, ktoré preukážu, že v krajine pôvodu majú opodstatnené obavy z prenasledovania z rasových, národnostných, alebo z náboženských dôvodov, zo zastávania politických názorov alebo príslušnosti k určitej sociálnej skupine. Doplnková ochrana je poskytnutá na obdobie jedného roka osobám, ktorým hrozí vážne bezprávie, mučenie, nel’udské zaobchádzanie alebo vážne ohrozenie života. 
a vec môže vrátit' na d’alšie konanie úradu hraničnej a cudzineckej polície alebo migračnému úradu.

Je potrebné uviest', že z dôvodov zdíhavého zist'ovania bolo v minulosti niekol'ko žiadostí o azyl v konaní aj viacero rokov. Súvisí to s faktom, že v konaniach so žiadost’ami o azyl je spravidla nedostatok dôkazových materiálov, preto je pohovor klúčovým zdrojom dát. $\mathrm{V}$ rozhodovaniach migračného úradu boli dôkazným materiálom predovšetkým prvé rozhovory z policajných oddelení a zo záchytného tábora. Ako konštatovali úradníci, aj v roku 2014 stále pretrváva presvedčenie, že „,najpravdivejšie údaje dostaneme v tom prvom rozhovore“. Po prvom rozhovore totiž predpokladali vplyv právnikov a iných osôb. Je tiež pozoruhodné, že faktografický nesúlad s neskorším interview bol pre úradníkov dôkazom nedôveryhodnosti žiadatel'a. Nesúlad nemusel byt' spôsobený len nepresnost’ami v tlmočení, ale aj spôsobmi vedenia pohovoru. Úradníci tiež uviedli, že „,podstatná čast’ sa snaží klamat“, a preto je ciel'om štátu tých l'udí, ktorí „,chcú zneužit' systém“", „eliminovat““.

V každom prípade sa jedná o komplexný proces, ktorý je výsledkom nielen geopolitických súvislostí a systémových nariadení. Na tomto mieste ma zaujíma, akými vyjadreniami zodpovedné osoby legitimizujú svoje rozhodnutia. Rozumiem aj tomu, že je náročné predpokladat', že aj v „tranzitnej krajine“ môže pred úradmi stát' osoba, ktorá podl'a slov úradníkov nie je ,plevel“". Rada by som poukázala na fakt, že osoba môže neuviest’ všetky údaje napríklad z dôvodu príslubu zachovania mlčanlivosti, z dôvodov životných zmien alebo z dôvodu chybného prekladu.

\section{Zodpovednost' a zodpovedatel'nost'}

Problémom absentujúcej ucelenej teórie právneho prekladu a otázkam preložitel'nosti sa na Slovensku venujú predovšetkým translatológovia (Guldanová 2013). Podobne ako Bázlik a Hrehovčík (2009) sa v textoch sústred'ujú najmä na presné ekvivalenty jazykového registra práva v súdnom preklade a tlmočení. Na zložitost' transferu legislatívnych textov medzi dvoma jazykmi, kultúrami, aj dvoma právnymi systémami upozorňuje Štefková (2013). Tento text poukazuje nielen na absenciu tlmočenia z jazykového registra práva, ale aj zo sociolektu úradníka do sociolektu žiadatel'a a naopak, nakol'ko v praxi sú tieto situácie in situ netlmočené.

Ked’ sa cudzinec dostane do situácie, v ktorej je odkázaný na rozhodnutie štátnej správy a potrebuje tlmočníka, je účastníkom špecifického druhu komunikácie. Prostredie, ktoré je založené na legislatíve, samo o sebe vyžaduje tlmočenie pre tých, ktorí neovládajú jazyk práva ani vo vlastnej reči. Navyše cudzinec je primárne socializovaný v inej spoločnosti a musí sa nanovo zorientovat' $\mathrm{v}$ prijímajúcej krajine, čo je celkovo náročný proces, ktorý nezačal pri prvom pohovore, či pri prekročení hranice. Cudzinec tak nemá ako rozumiet' prekladu bez kultúrnych kontextov a vysvetlení.

Z toho vyplývajúca bezradnost' súvisí aj s vnímaním kultúrnych odlišností migrantov a postojom k ich integrácii (Kadlečíková, Gallová Kriglerová, Gažovičová 2011; Bargerová, Fajnorová, Chudžíková 2011). Predpokladám, že už samotné uvedomenie si kultúrnej odlišnosti zvyšuje kvalitu tak vedenia pohovoru, ako aj tlmočenia. 
V tomto zmysle aj v sociálno-vedných disciplínach nastáva v posledných rokoch obrat k pozitívne definovaným požiadavkám, na rozdiel od kritiky inštitucionálnych postupov opisom negatív. Za silnejšie ako kritiku inštitucionálnych nedostatkov považujem pomenovanie očakávaní a potrieb všetkých aktérov (žiadatel’ov, tlmočníkov, rozhodovatel’ov aj pozorovatel'ov):

- môct' sa pýtat'

- môct' odpovedat'

- môct' dopovedat'

- môct' byt' ticho

- vypočut' a byt' vypočutý

- porozumiet' a byt' porozumený

- byt' v úcte

- byt' v práve

Tieto požiadavky sa môžu javit' ako elementárne, ale v rozhovoroch so žiadatel'mi boli uvádzané najčastejšie, a napriek tomu boli v praxi prehliadané. Od každej zo strán sa očakávala zodpovednost' a neraz ňou rozhodovatelia legitimizovali uznesenia o žiadatel'och. Tento pojem nadväzuje na zodpovedanie, teda na odpovede. Predpokladám preto, že so zodpovedaním tak súvisí nielen zodpovednost', ale aj zodpovedatel'nost', teda vytvorenie kontextu, ktorý odpoved' vôbec umožňuje.

V tomto zmysle žiadatelia očakávajú vytvorenie priestoru pre otázky aj odpovede. Migranti (ako aj iné marginalizované skupiny) sú však bežne znevýhodnené tým, že boli socializované $\mathrm{v}$ inej kultúre, jazyku, uznávajú iné hodnotové hierarchie a spoločenské pravidlá ako majoritná resp. dominantná spoločnost' a kultúra (viac Tužinská 2009b). Predstavitelia kritickej právnej teórie upozorňujú na túto skutočnost' a na to, ako právo, najmä ak je používané mechanicky, je v kontexte života týchto l'udí vnímané ako nespravodlivost' a nemožnost' integrácie. ${ }^{5}$

Javí sa tak, že rozhodovatelia majú inštitucionálne danú moc nad formou aj obsahom rozhovorov, ale na zodpovednost' sú braní žiadatelia, ktorí sú znevýhodnení iným porozumením formy aj obsahu. Spôsoby, akými sa aktéri vyrovnávajú s týmito výzvami, sú rozmanité.

5 D. Mackovej a Z. Bargerovej d’akujem za poznámku aj za nasledujúci príklad: niektorí sudcovia kritizujú právny formalizmus $\mathrm{v}$ rozsudkoch a komentujú dodržanie či rozpor s princípom proporcionality. K „formalizmu“ dochádza v praxi vel'mi často, ale nakol'ko to nie je podstata práva, aj právnici sú vo vzdelávaní vedení, aby výklad právnej normy neprebiehal iba gramaticky, preto sa v práve hovorí o princípoch, zásadách, či duchu zákona. Z nálezu ústavného súdu vyplýva, že aj na Slovensku je snaha o kontextuálnu judikatúru, vid’ sp. zn. I. ÚS 243/07: „Vo všeobecnej rovine nemožno presne vyjadrit' hierarchiu jednotlivých interpretačných argumentov ani špecifikovat' okolnosti, za ktorých má mat' jednotlivý argument prednost' pred argumentom iným. Súd musí prihliadat' $\mathrm{k}$ vzájomným vzt’ahom jednotlivých do úvahy pripadajúcich argumentov a ich úlohu v konkrétnom prípade vyvážit's ohl'adom na špecifikum danej kauzy, a nie tieto kritériá iba mechanicky aplikovat'. Takýto prístup je zároveň prístupom modernej judikatúry, ktorá postupne nahrádza formálne legalistický pohl’ad na právo pohl’adom, ktorým sa sudca usiluje poskytnút najlepšie vyargumentovanú odpoved' na právne a skutkové otázky, ktoré pred neho strany sporu predložia.“ 
Napríklad priekopnícka práca sociolingvistky Diany Eades (2010), ktorá je známa fundovanou obranou Aborigénov v kontakte so štátnou správou, poukazuje na dva základné prístupy. Analýzy dát by sa podl'a nej dali rozdelit' na tie, (1) ktoré analyzujú spolu s textom aj kontext a tie, (2) ktoré sa zaoberajú predovšetkým textom. Eades (2010) tiež prízvukuje, že formalizmus je v tomto smere rovnako prítomný aj v dielach sociálnych vedcov.

Principiálne blízke delenie uvádza aj lingvistická antropologička Susan U. Philips (1998), ktorá kategorizovala sudcov na (1) orientovaných na proces a (2) orientovaných na zápis. Právny antropológ Anthony Good (2007) opísal analytické nástroje antropológie ako prevažne (1) deskriptívne, a práva ako viac (2) preskriptívne. V rámci tejto interpretácie sa javí, ,akoby boli právnici viac orientovaní na pravidlá (rule-oriented), kým antropológovia sú priam zaviazaní, aby boli orientovaní na vzt’ahy (relationally-oriented)“ (Good 2007: 30). Translatologička Cecilia Wadensjö (1998) konverzačnou analýzou prejavov tlmočníkov poukázala tiež na dva typy tlmočenia: (1) kontextuálne, dialogické, interakcionistické alebo (2) doslovné, monologické. Forenzný lingvista John Gibbons (2003) v bežnom prejave zdôraznil (1) vol'nost', kým v jazyku právneho systému (2) presnost'.

Predpokladám tak, že so zásadnými nedorozumeniami, ktoré som pozorovala pri tlmočení cudzincom v štátnej správe, súvisia uvedené prístupy v komunikácii:

Tabulka 1: Prehl'ad rôznych typov tendencií v komunikácii

\begin{tabular}{|l|l|}
\hline $\mathbf{1}$ & $\mathbf{2}$ \\
\hline kontext & text \\
\hline proces & zápis \\
\hline kontextuálne ponímanie & mechanické a legalistické ponímanie \\
\hline volnost & presnosf \\
\hline interakcionistické & jednosmerné \\
\hline dialogizmus & monologizmus \\
\hline responzívne & reaktívne \\
\hline orientácia na vzfahy & orientácia na pravidlá \\
\hline opisujúce & predpisujúce \\
\hline deskriptivita & preskriptivita \\
\hline
\end{tabular}

Ak by som mala zhrnút' deklarované postoje aktérov $\mathrm{z}$ rozhovorov ako aj z národných správ, tak v praxi tlmočenia cudzincom je „V mene kontextu“ zvyčajná odpoved’ (v zmysle re-sponse, počúvanie, zodpovedatel’nost'), kým „V mene zákona“ je zvyčajná reakcia (v zmysle re-action, čin, zodpovednost'). V pohovoroch na hraniciach, úradoch či súdoch je rozdiel medzi responzívnym a reaktívnym správaním pozorovatel'ný aj $\mathrm{v}$ spôsobe vedenia pohovoru ako takého, niekedy i v kladení otvorených a zatvorených otázok, v opise, či vo vyplnení dotazníka (Tužinská 2010, 2011b).

Zvyčajne preskriptívnost' predurčuje vnímanie správania aj výpovedí cudzincov v prospech udržania systému. Na druhej strane deskriptívnost' umožňuje analýzu správania a výpovedí v kontexte, ktorý zohl’adňuje perspektívu všetkých zúčastnených, teda aj cudzincov. Prístupy orientované na regulácie na jednej strane a prístupy orientované na vzt’ahy na druhej strane sa môžu dostávat' do interpretačného konfliktu, ale môžu mu i predíst'. 
Hoci deskriptívne postupy sú $\mathrm{v}$ administratívnom prostredí paušálne kritizované ako neuplatnitel'né - niekedy pre nedostatok času, alebo aj pre principiálnu inakost'- aktéri v praxi očakávajú porozumenie a z neho plynúcu spravodlivost'. Aj ked’ je zrejmé, že každý hovorí z pozície vlastnej profesie, málokedy sa venuje pozornost' tomu, ako sa spolutvoria a ako v praxi fungujú predstavy, aké je to „byt' úradníkom“, „byt' sudcom“, „byt' žiadatel’om“.

Domnievam sa však, že je dôležité, aby sa sociálnovedné poznatky o komunikácii, či dokonca vybrané etnografické techniky interview stali súčast'ou praxe úradníka či sudcu. Ako uvidíme v nasledujúcej časti, rozhodovatel', ktorý integruje sociálnovedné poznatky do svojej praxe, nemusí byt' $\mathrm{v}$ rozpore s vlastným poslaním.

\section{Procesne a zápisne orientovaný rozhodovatel'}

Rozdielnosti v preskriptívnych a deskriptívnych postupoch, ktoré Philips (1998) ukázala na príklade opisu správania sudcov, aplikujem aj na role rozhodovatel’ov a tlmočníkov. V jej ponímaní pri „procedure oriented“ ide skôr o súdne konanie vnímané a používané ako prostriedok k rozhodnutiu, a zároveň aj k porozumeniu konkrétneho prípadu. Druhý prístup „record oriented“ (orientácia na zápis) je konanie zamerané skôr na dosiahnutie výsledku, t.j. súdneho rozhodnutia, ku ktorému sudca dospeje formálne správnym, štandardizovaným postupom.

Podobne typológiu praktizovania práva, politiky a kontroly môžeme aplikovat' aj na príslušníkov Policajného zboru a úradníkov, ktorí preverovali detaily životov žiadatel'ov. Podl'a Philips (1998) tí, ktorí používajú stratégie zamerané na proces, viac variujú svoj postup od prípadu k prípadu. Veria, že pre efektívnu komunikáciu je potrebné prispôsobovat postup „šitý na mieru“.

Naopak, tí, ktorí sú orientovaní na zaznamenávanie, sú presvedčení, že nemusia svoj postup individuálne prispôsobovat'. Zameriavajú sa predovšetkým na štandardizáciu svojho postupu. Vedia, že nesú spoluzodpovednost' za to, aby obvinenie bolo podchytené dôkladným zápisom, a chcú sa poistit pred vrátením prípadu dôkladným dodržaním litery zákona (Philips 1998: 49). Preskriptívne interpretácie sú tak vlastné prevažne tým rozhodovatel'om, ktorí majú slovami žiadatel'ky „,premeditated talk“, t.j. pred-myslený, pred-písaný prejav, či pred-vyplnený dotazník.

Viacerí žiadatelia sa cítili ponížení, ked' v nápovedných alebo zatvorených otázkach necítili „otázku“, ale naopak, potvrdenie niečoho, čo už rozhodovatelia predpokladali (viac pozri Tužinská 2009a, 2010, 2011b). Žiadatelia neraz uvádzali, ako im bolo už z neverbálneho správania zrejmé, nakol'ko majú priestor vypovedat'. Na oboch stranách, ešte pred začatím komunikácie žiadatel’a a rozhodovatel'a, sa deje stereotypizácia: „Čokol'vek poviem, pozerajú na mňa ako na naničhodného žobráka. Zaobchádzajú s nami výlučne ako s ekonomickými migrantmi. Dostávam nálepku skôr, ako som niečo vyslovil. Mám pocit, že bolo rozhodnuté ešte skôr, ako som vošiel do miestnosti." ${ }^{6}$

$6 \quad$ Z rozhovoru žiadatel'a a autorky v roku 2014. 
Zápisne orientovaní sudcovia podl'a Philips (1998) nevidia svoju rolu ako ochrancovia práv jednotlivcov, skôr hl'adajú dôkazy o tom, ako iní (právnici, polícia) už informovali jednotlivca o jeho právach. Nepýtajú sa na sociálne zázemie dotknutých osôb, nevenujú rozsiahlu pozornost' vysvetl'ovaniu a pochopeniu práv vyplývajúcich so zákona. Pridŕžajú sa predovšetkým vlastnej perspektívy a vlastného štýlu zist'ovania. Odvolávajúc sa na spis, otázky kladú len na overenie vlastnej sumarizácie. Sudcovia zameraní na zápis kladú neporovnatel'ne menej otázok, aj to zatvorených, než sudcovia zameraní na proces. Viac používajú individuálne rutiny a majú málo variácií medzi procedurálnymi postupmi (Philips 1998: 77-79).

Predpisujúco sa správali aj viacerí príslušníci Policajného zboru a úradníci: hovorili menej o žiadatel'ových právach, menej sa pýtali a overovali, či a ako žiadatel' porozumel, aký je jeho/jej pohl'ad. Legalistické ponímanie je viazané na presnost', ktorá žiadatel'ovi prináša pocit odosobnenosti, až nel'udskosti, kedy je definovaný ako „číslo spisu“.

Naopak, deskriptívne prístupy sa podl'a Philips (1998) v správaní rozhodovatel’ov prejavujú v tom, že potrebujú mnohé zist'ovat'. Procesne orientovaní rozhodovatelia majú detailnejšie záznamy, rozhodnutia a rozsudky. Kladú viac otvorených otázok, počúvajú a dostávajú viac odpovedí. Žiadatel'ov viac zapájajú, čo je pre všetkých jednoznačne náročnejšie, avšak tým si zaist’ujú spätnú väzbu a porozumenie prípadu. Majú rovnostárskejší prístup, menej kontrolujúci, svoje postupy viac ,šijú na mieru“. Opakovane si overujú, nakol'ko prítomní pochopili svoje práva, a zist'ujú, z akého sociálneho prostredia pochádza žiadatel'. Sú liberálnejší, osobne sa zasadzujú za ochranu práva jednotlivcov ako zástupcovia štátu. Majú neformálnejší štýl, sú menej kontrolujúci, chcú aktívnych účastníkov a sú ochotní obetovat’ dojem vlastnej kontroly v prospech ochotnej účasti žiadatel’a (Philips 1998: 59, 74-79, 112).

Dá sa povedat', že na všetkých úrovniach, od polície, cez úrady až po súdy boli aj takí rozhodovatelia, ktorí sa snažili pochopit’ perspektívu inú než svoju vlastnú. Overovali si správnost' vlastnej interpretácie toho, čo počuli, a pomáhali žiadatel'ovi v uvedomení si ich vlastných formulácií. Na tréningoch aj v objasňovaní prípadov postupovali pružne a sociálnovedné poznatky považovali vo svojej práci za prínosné.

Napríklad na jednom zo seminárov pre príslušníkov Policajného zboru v roku 2014 jedna z účastníkov uviedla, že v zaist’ovacom zariadení pre cudzincov pohovor vedie otvoreným a porozumejúcim spôsobom, za čo neraz zožne kritiku kolegov, ale jej skúsenost' ju podporuje v tom, že tento prístup uplatňuje nad'alej. Naopak na workshope v roku 2012 na východnej hranici Slovenska sa iná príslušníčka Policajného zboru vyjadrila, že aj by mohli súhlasit' s etnografickými prístupmi v interview s migrantami, ale ich princípy vníma v konflikte s prvoradým ciel’om ich služby, pretože „My sme tu predovšetkým preto, aby sme chránili hranicu!“‘

Ochrana hranice sa tak neraz prenášala do udržovania odstupu aj v komunikácii. Inými slovami, ,ked’že formalita navodzuje pocit nadradenosti, ak sú menej formálni, pôsobí to, akoby strácali kontrolu“ (Philips 1998: 121). Predpokladám, že práve domnelá strata kontrolovania rozhodovatel'a podnecuje vzájomné počúvanie, porozumenie a plynulejší tok informácií charakteristický aj pre etnografické interview.

Na základe pozorovaní sa tiež domnievam, že v konaní príslušníkov Policajného zboru, tlmočníkov, právnikov i sudcov sa v komunikácii prejavovala ideológia ne/ústretovosti voči 
cudzincom, od ktorej sa odvíjali napríklad spôsoby, akými sa žiadatel'ov pýtali a ako ich odpovede interpretovali. Prejavy ideológie v jazyku priznáva aj Philips (1998): „Je nedorozumením mysliet' si, že sudcovia sú neideologickí implementátori práva, ktoré vyrobili iní. To by platilo v prípade, ak by sme za právo považovali len písané právo. Hovorené právo má však život sám o sebe, svoju logiku a princípy, ktoré sú od písaného práva oddelené a nemôžu v ňom byt' nájdené“ (Philips 1998: 123).

V tomto zmysle som v porovnávacej správe identifikovala, že osoba, ktorá vedie pohovor, robila v niektorých prípadoch zásahy, ktoré st’ažovali rozprávanie ako aj kvalifikované tlmočenie: nevysvetlením postupu celého konania cudzincovi, nepripravenost'ou na pohovor, preukazovaným odporom voči inakosti, nedôverou voči cudzincom, neúctivou komunikáciou, nepozorným vnímaním, rýchlym vedením interview, kladením zatvorených otázok, častým prerušovaním odpovedí, vlastným preformulovaním výpovede do nedoslovného zápisu, neprítomnost' audiozáznamu, nevydaním kópie zápisnice cudzincom, nedodržiavaním profesných štandardov a zákonných postupov, neverbálnymi a verbálnymi prejavmi osobného a inštitucionálneho postoja voči cudzincom. Takéto správanie bolo časté pre zápisne orientovaných rozhodovatel'ov.

Správanie procesne orientovaného rozhodovatel'a bolo tiež v zhode s výsledkami porovnávacej správy. Ten si bol vedomý, že na priebeh konania so žiadatel'om ako aj na kvalitu tlmočenia má zásadný vplyv: miera vysvetlenia postupu celého konania cudzincovi, miera pripravenosti na pohovor, postoj voči inakosti, miera dôvery medzi komunikujúcimi, miera vzájomného rešpektovania, miera pozornosti počas počúvania, rýchlost' vedenia interview, otvorenost' kladených otázok, frekvencia prerušovania odpovedí, presnost' a vernost' zápisu, prítomnost' audiozáznamu, obdržanie kópie zápisnice cudzincom, miera dodržiavania profesných štandardov, neverbálne a verbálne prejavy osobného a inštitucionálneho postoja voči cudzincom. ${ }^{7}$

Deskriptívne prístupy v tlmočení idú tak ruka v ruke s kontextuálnym ponímaním interpretácie a aplikácie práva, ako aj s vedením rozhodovatel'a, ktorý zohl'adňuje najmodernejšie poznatky sociálnych vied o l’udskej komunikácii a spôsoboch kladenia otázok v hraničných životných situáciách. Odhliadnuc od toho, či je rozhodovatel' procesne alebo zápisne orientovaný, obaja čelili výzve písomného zachytenia hovoreného slova.

\section{Vol'nost' a presnost' prejavu, hovorené a písané slovo}

Interakcia písaného a hovoreného jazyka na policajných oddeleniach, na migračných úradoch a na súdoch ústi do právneho prepisu. Je známe, že písanie vo všeobecnosti nie je dobrý nástroj na zaznamenanie reči, lebo editovaním vynechá kontextuálne detaily. Tento konflikt vol'nosti a presnosti v prejave musia riešit' všetci aktéri pri každej interakcii, ktorá vyžaduje tvorbu zápisnice. Hovorené slovo sa musí stat' písaným a rozhodovatelia ho sumarizujú, ale tým pádom aj menia.

7 Pre konkrétnejšie príklady pozri (Tužinská 2009a, 2010, 2011b, 2015) a tiež Barsky (2000), Eades (2010), Wadensjö (1998) a Gibbons (2003), pre príklady zo súdneho anglo-hispánskeho prostredia imigrantov pozri Berk-Seligson (2002). 
Závažným zistením je fakt, že v skutočnosti sú zápisnice, ktoré sú deklarované ako doslovné zápisy, zmenenou verziou povedaného (Berk-Seligson 2002; Eades 2008, 2010; Gibbons 2003; Good 2007; Maryns 2006). Štylistická zmena výrokov žiadatel'ov môže menit' aj ich význam, a niekedy až tak, že sa dá súhlasit' s konštatovaním, že „snaha o presnost' spôsobila zahmlenie“" (Gibbons 2003: 73). Počas sumarizácie rozhodovatelia štandardizujú, dekontextualizujú, editujú, pridávajú neosobnú štylizáciu, vynechávajú zápis neverbálneho správania (pohyby tela, smiech, plač), a niekedy aj prejavy, ktoré boli kontextuálne zásadné (napríklad váhanie, mlčanie, spýtavý pohl’ad). V mnohých prípadoch sa viac ako $70 \%$ interview pri prepisovaní stratí (Gibbons 2003: 31-33).

$\mathrm{V}$ praxi som často zaznamenala dekontextualizované sumarizácie, ktoré vskutku viedli $\mathrm{k} \mathrm{z}$ oboch strán nežiadúcemu neporozumeniu žiadatel'ov a rozhodovatel'ov. Ako príklad uvádzam čast' prepisu z roku 2007 z Najvyššieho súdu v Bratislave, ktorý vd’aka výnimke sudkyne vypočut' si vysvetlenie námietky odporcu napokon skončil v prospech žiadatel'a.

Sudkyňa: Pán navrhovatel' podal odvolanie. Nie je potrebné, aby povedal to, čo pred Krajským súdom a na Migračnom úrade, to máme v spise. Teraz potrebujeme len vediet', či trvá na podanom odvolaní a či ešte chce niečo dodat'. Nech sa páči, môžete ostat' sediet', alebo chce aby sa vyjadrila rovno jeho právna zástupkyn̆a? Lebo nemusi hovorit'.

Tlmočník: On by vám chcel ukázat' jeho poranenia, ktoré utŕžil.

Žiadatel' ukazuje.

Sudkyňa: Máme v spise lekárske správy, ktorými sú tieto poranenie popisané?

Advokátka: Áno.

Tlmočník: On sa nechce vrátit’ do jeho krajiny, lebo by prišiel o život, bol 4 mesiace zadržiavaný, $v$ žiadnom prípade sa vrátit’ nemôže.

(...)

Sudkyňa: Navrhovatel' trvá na svojom odvolani a udáva, že domov sa nechce vrátit', lebo tam by mu šlo o život, bol 4 mesiace zadržiavaný. Ukazuje hlboké jazvy na ruke aj nohe ako následky spôsobených zranení.

(Všimnime si, ako sudkyňa sumarizuje. Tlmočník preložil žiadatel'ovu výpoved' nie že nechce, ale nemôže, nepovedal šlo o život, ale by prišiel o život.)

(...) Hovorí zástupca Migračného úradu, sudkyňa diktuje jeho výrok zapisovatel'ke bez tlmočenia, jej posledná veta je:

Sudkyn̆a: Navrhovatel' sa pred odchodom z krajiny zdržiaval na inom mieste, z čoho vyplýva, že nebol vystavený prenasledovaniu.

Advokátka sa nesúhlasne zhboka nadýchne, že chce niečo povedat'.

Sudkyňa: Repliky nepripúśt’ame, lebo to by bolo donekonečna, ale môžeme dat' výnimku.

(...) Advokátka vysvetl'uje, sudkyňa následne diktuje do zápisnice zásadnú zmenu.

Sudkyňa: Právna zástupkyňa upresňuje, žiadatel’ nebol v inej časti krajiny, ale v inej štvrti, a že sa skrýval. Pán tlmočník uplatnite tlmočné.

(...) Prítomní sa vzdialili a vrátili do súdnej siene na vypočutie rozsudku.

Sudkyňa: Súd rozhodnutie odporcu (t.j. Migračný úrad) zrušuje a vec vracia na d’alšie konanie.

Sudkyňa sa otočí a díva sa do očí zástupcovi z Migračného úradu.

Vyhodnotili sme danú vec inak, aj sme zohl'adnili súčasnú situáciu v krajine. Písomný rozsudok bude doručený, proti nemu opravý prostriedok nie je prípustný. To je všetko, môžete sa vzdialit'. 
V predošlej ukážke zo súdnej siene bolo ukázané, ako „konštrukcie, ktoré vzniknú pri interpretovaní svedectiev, sú často uvedené ako ,fakty“ prípadu. Proces, ktorý sa nazýva uplatnenie práva, zahŕn̆a ,zapasovanie‘ rekonštruovaných udalostí do právnych predstáv klasifikovaných v legislatíve“ (Gibbons 2003: 149). V tomto zmysle Gibbons upozorňuje, že je pochopitel'né, že „na strane príslušníkov Policajného zboru môžeme sledovat' odpor voči hl'adaniu pravdy s mnohými odtieňmi, pretože skôr vidia svoju rolu v získavaní dôkazov pre usvedčenie“ (Gibbons 2003: 147). S tým súvisí fakt, že ,špeciálna pozornost’ je v zákonoch venovaná otázke, viny“. To znamená pripisovanie zodpovednosti za udalosti konkrétnym účastníkom. Zodpovednost’ za udalosti je ústredným záujmom právneho naratívu“ (Gibbons 2003: 155).

Je tiež pozoruhodné, ako rozdielne môžu aktéri rozumiet' kategórii presnosti. Jednoznačnost' a nedvojznačnost' pre rozhodovatel'a môže znamenat' pre žiadatel'a neosobnost', pretože mechanickost' je súčast'ou vypĺňania formulárov. Rozhodovatelia musia stlačit' do inej formy presne to, čo žiadatelia podali vol’ne v inom kontexte. Pre úradnícky záznam preskriptívneho typu je charakteristické, že v zápisoch sú chyby štátneho úradníka opravované, kým žiadatel'ove chyby sú zaznamenávané, a neskôr argumentačne zdôraznené.

Následne, čo presne znamená presnost' záznamu, môže byt' v praxi pre obe strany rozdielnou otázkou. Z týchto dôvodov Gibbons (2003: 110) navrhoval, aby bol k dispozícii nielen etický kódex danej profesie, ale aj kódex pre rozhodovatel'ov týkajúci sa vedenia interview. Ak takéto pravidlá absentujú, skôr dochádza $\mathrm{k}$ vedeniu pohovoru podl'a zvykového práva, alebo intuitívne.

Napríklad príslušníci Policajného zboru neinformovali cudzinca vopred, nakol'ko detailná má byt' ich správa, ani aké typy faktov má obsahovat'. V diskusiách uviedli, že prílišným vysvetl'ovaním by mohli „,napovedat'“. To, že cudzinec nemal znalost' formátu, považovali za výhodu v dokazovaní ich ne/dôveryhodnosti. Pohovor na hraniciach bol stručný, a teda zjednodušujúci. Migrantom bolo povedané, že neskôr budú môct' rozpovedat' svoj príbeh obšírnejšie. Z toho vyplýva, že zápisnica o dôvodoch podania žiadosti o azyl bola spravidla neúplná, ale niekdy aj kvôli emocionálnemu stavu cudzinca či absencii kvalifikovaného tlmočenia. Ak bol tlmočník svedkom nepresného záznamu výpovede a snažil sa objasnit' význam fráz, bol vo viacerých prípadoch úradníkom zastavený. Problém nastal až v d’alšom konaní: vzhl'adom na podmienky zápisu, záznam z hraníc niektorí považovali za zásadný, iní za marginálny, avšak bol pre nich dostatočne relevantný na to, aby faktografický nesúlad s neskorším interview slúžil pre spochybnenie dôveryhodnosti žiadatel'a.

Cudzinec mal zo zákona nárok dostat' kópiu zápisnice po ukončení interview, a to bez povinnosti písomného zdôvodnenia či ústneho požiadania, bezplatne a bezodkladne. Cudzinci, úradníci aj právnici uvádzali, že nie vždy sa tak stalo, a nie vždy bol k dispozícii kvalifikovaný preklad zápisnice. Presnost’ rozhodnutia závisela na presnosti tlmočenia, ale nepresné tlmočenie malo dôsledky pre cudzinca. Ostáva otázkou, do akej miery si príslušníci Policajného zboru, úradníci aj sudcovia boli vedomí dosahu sumarizujúcich zápisníc, v zmysle „co je psáno, to je dáno“.

$\mathrm{V}$ prípade, že spôsoby vedenia interview boli medzi príslušníkmi Policajného zboru, úradníkmi aj sudcami prevažne preskriptívne, pre žiadatel'ov to znamenalo nielen zdĺhavé dokazovanie, ale niekedy aj stratu cti. S chýbajúcim rešpektom voči rôznym kultúrnym 
identitám súvisí otázka, či je „úplná rovnost’ pred zákonom prakticky dosiahnutel'ná a teda, či je politika slepá k odlišnostiam (kultúrne neutrálna) vôbec možná“ (Gallová Kriglerová, Kadlečíková 2009: 20).

\section{Dialogické a monologické tlmočenie}

Tlmočenie predstavuje komplexný problém, ktorý zahíňa nielen zohl'adnenie rozdielov v právnych kultúrach, ale aj inštitucionálne určované štandardy, príslušnost’ k sociálnym identitám všetkých aktérov a mnoho iných faktorov. Najprv by som opísala východiskovú situáciu žiadatel'ov so zretel'om na podmienky tlmočenia.

Tak v krajinách V4 a na Ukrajine ako aj v zahraničí pre nedostatok kvalifikovaných tlmočníkov nebolo zriedkavost’ou, že tlmočil jediný dostupný tlmočník. Dôsledky neodborného prekladu ako aj riziko odovzdania informácí tretej osobe znášal žiadatel'. Ak sa tlmočilo cez rodinného príslušníka, iného migranta či úradníka, títo získali prístup k osobným údajom. Cudzinec nemusel mat' $\mathrm{k}$ takému tlmočníkovi dôveru, a tak výpoved' prinajmenšom nebola celistvá.

Z uvedeného vyplýva, že cudzinec mal opodstatnený strach, ak by sa st’ažoval na tlmočníka počas pohovoru. Boli zaznamenané aj prípady, kedy tlmočník zneužil zranitel’nost' migranta, požadoval finančné kompenzácie, udržoval ho v nepravdách či v obchodovaní s l'ud'mi. Ked' žiadatelia spomínali na prvé stretnutie s tlmočníkom, uviedli, že niekedy tlmočník ich výpoved' považoval za nedôležitú a ich prejav skracoval. Ak aj v d'alšom interview cudzinec uviedol, že došlo $\mathrm{k}$ posunom $\mathrm{v}$ jeho vlastných údajoch alebo $\mathrm{v}$ tlmočení, bolo mimoriadne náročné vykonat' nápravu. Dodatočné objasňovanie totiž úrady často interpretovali ako zavádzajúce až kontradikčné vyhlásenie. Ak aj cudzinec uviedol, že to, čo je uvedené v zápisnici, nepovedal, neexistoval o významovom posune dôkaz. Podobne tlmočníci uviedli, že žiadatelia mohli skresl'ovat' ich prácu zo špekulatívnych dôvodov. K vyjasneniu výpovede aktéra dospeli obvykle až na Najvyššom súde.

Niet divu, že st’ažnosti voči nesprávnemu tlmočeniu neboli úradne zaznamenávané, pretože (a) cudzinci nechceli oslabovat' už i tak vlastnú znevýhodnenú pozíciu, (b) cudzinci a tlmočníci mohli byt' krajanmi, (c) prípadné chyby vo vedení a tlmočení interview boli pre absenciu audiozáznamu nedokázatel'né. Podpisom každej strany zápisnice cudzinec vyjadril súhlas s jej znením, aj ked' mohol mat' o presnosti tlmočenia pochybnost'. Navyše, zápisnica bola $\mathrm{v}$ štátnom jazyku a cudzinec niekedy neobdržal jej kópiu napriek zákonnému nároku.

Žiadatelia tiež uvádzali, že v niektorých prípadoch nemali spätný preklad znenia zápisnice, alebo bol zostručnený. $\mathrm{V}$ prípade prítomnosti právneho zástupcu (ak ho žiadatel' kontaktoval) bolo tlmočenie dôkladnejšie, čím sa zaistila dôkladnost' spätného tlmočenia zápisnice a tým aj možná oprava. Aj preto žiadatelia aj niektorí tlmočníci navrhovali, aby aspoň v prípade neprítomnosti právneho zástupcu mali audiozáznam, ktorý by umožnil spätné zhodnotenie námietok voči tlmočeniu.

Okrem uvedeného, podl'a údajov od žiadatel'ov, ako aj rozhodovatel'ov a právnikov, neprofesionálny tlmočník niekedy preberal funkcie: (1) rozhodovatel'a, rozhodujúc o opodstatnenosti údajov; (2) právnika, poskytujúc právne rady cudzincom, ako ne/žiadat’ o azyl; 
(3) príslušníka Policajného zboru, ponúkajúc pomoc s prepustením či vybavením dokladov; (4) sociálneho pracovníka, vyjadrujúc sa k jeho integrácií; (5) psychológa, vedúc terapeutický rozhovor; (6) experta na krajinu pôvodu, porovnávajúc údaje z krajiny pôvodu, či vyjadrujúc sa k pravosti etnických a kultúrnych prejavov, a tým k dôveryhodnosti cudzinca.

Je potrebné podotknút', že tlmočník sa niekedy staval do uvedených pozícií bez toho, aby mu inštitúcia zamedzila v takomto konaní.

Na tomto mieste by som upriamila pozornost' na situácie, v ktorých rozhodovatel' neponechal priestor na interpretáciu ani žiadatel’ovi, ani tlmočníkovi. Príklad pochádza z pozorovania z Krajského súdu Bratislava I z roku 2007, ked' rozhodovatel' vopred upozornil prítomných, že on vyberie, čo bude hodné zápisu, a teda aj pretlmočené.

Sudca: „Budete tlmočit’ to, čo vám poviem, aby ste tlmočili. Nie je potrebné tlmočit' všetko, nakol'ko je prítomný právny zástupca. On (žiadatel') musí požiadat' o dovolenie, ak chce niečo povedat' súdu a pri tom musí stát."“

Napriek povedanému, tlmočníčka, jedna z mála, ktorá tlmočila tzv. šušotážou, začala tlmočit' simultánne do ucha žiadatel'a, a vzápätí bola sudcom opätovne upozornená.

Sudca: „Netlmočte, vyrušuje ma to. Pani magistra, veci, ktoré uzná za vhodné súd, tie budú pretlmočené."

Želanie rozhodovatel'ov zjednodušovat' si komplikovanú situáciu je v zhode s rozšíreným stereotypom tlmočníka, ktorý motívy a stratégie podáva výlučne z pohl'adu hovoriaceho, akoby v sociálnom vákuu. Wadensjö (1998) tak opisuje monologický model sprostredkovatel’a, kde je rola tlmočníka ako goffmanovská non-person: tlmočník je ako nestranný katalyzátor, médium prenosu, žiadna tretia strana. V tomto zmysle sa normy tlmočenia berú ako samozrejmost' miesto toho, aby boli problematizované, lebo normatívne myslenie pokladá za monologické. Všíma si tiež otázky preložitel'nosti v dvoch rozličných kontextoch: tlmočenie ako kontrola alebo tlmočenie ako služba. Wadensjö (1998) d’alej tvrdí, že tlmočníci majú dilemy z týchto protirečivých požiadaviek a očakávaní. „Právna zodpovednost’ tlmočníkov predpokladá textový model reči. Súdni prekladatelia majú len prekladat', doslovne prekladat' a neinterpretovat'. Táto predstava je však v rozpore so súčasnými poznatkami o jazyku a komunikácii“" (Wadensjö 1998: 45).

V prípade, že tlmočníci prekladajú v tomto textovom modeli, poslucháči prichádzajú o možnost' vnímania jazykových variácií. Podl'a Gibbonsa (2003) sú variácie spájané s rôznymi geografickými regiónmi (dialekt), socioekonomickým statusom (sociolekt) a rôznym kontextuálnym použitím jazyka (register) (Gibbons 2003: 305). Podstatné však je, že prínos prekladov medzi dialektami, sociolektami a registrami zväčša rozhodovatelia nepovažovali za signifikantný.

Kvôli nepriznaniu vplyvu dialektov, sociolektov a registrov som zaznamenala významové posuny, najmä počas diktovania zápisnice. Rozhodovatelia vykonávali zmeny: (a) z prvej na tretiu osobu, (b) z trpného na činný rod a naopak, (c) rôznych gramatických časov, ktoré menia význam viet, (d) vo výrazovosti, (e) v lexike, gramatike, diskurze a tiež vynechali záznam o prebiehajúcej neverbálnej komunikácii. 
Týmito spôsobmi sa autorstvo žiadatel’a strácalo nielen v tlmočení, ale hlavne pri zápise z pohovoru, ktoré bolo obvykle zvláštnou zmesou toho, čo žiadatel' povedal, tlmočník pretlmočil a rozhodovatel' zosumarizoval.

Stret dvoch registrov, akými je „každodenný konverzačný jazyk, neformálny, nešpecializovaný, s malými mocenskými rozdielmi a na druhej strane je dekontextualizovaný, formálny, špecializovaný a mocou zat’ažený jazyk legálneho systému“ (Gibbons 2003: 128), nie je l'ahké preklenút'. Aj z týchto dôvodov zmena registra bola častá, ako uvidíme v nasledujúcom výroku sudcu, ktorý z hovorovej reči žiadatel'a vyabstrahoval zmysel a nadiktoval ho do zápisnice jazykovým registrom práva.

Sudca: „Pojednávanie číslo 2 NRSR. Pritomní tlmočnik, žiadatel’ o azyl, migračný úrad, vymenoval členov senátu. Súd sa oboznámil so spisom, rozhodnutím Krajského súdu, ktorý napadnuté rozhodnutie odporcu potvrdil, neudelený azyl, ani zákaz vyhostenia do A., žiadatel' nebol väznený... súd dospel k názoru, že nebola preukázaná opodstatnenost' obáv žiadatel'a. Neexistujú dôvody, ktoré by bránili slobode pohybu v A. Proti uvedenému rozsudku navrhovatel' podal opravný prostriedok. Uviedol, že so skutkovými a právnymi zisteniami odporcu nesúhlasí a že svojou výpoved'ou dostatočne zdôvodnil opodstatnené obavy, že situácia je zložitá, základné práva a súdnictvo je neefektivne, je tam zastrašovanie, nefunguje vo vidieckych oblastiach, že sa odporca nazdával, že by mu hrozilo väzenie, $v$ krajine pretrvávajú útoky zo strany nevládnych militantných skupín, preto sa do A. nemôže vrátit'.“

Sudca voči tlmočníkovi: „Takže keby ste mohli preložit, že som oboznámil spisový materiál, či trvá na tom.“ (...)

Žiadatel' voči tlmočníkovi: „Dobre vieme, že bezpečnostná situácia v A. je horšia než lepšia. Minulý týždeň bolo 15 trestov smrti. Ani nemáme občiansku bezpečnost'. Nie je situácia, aby som tam mohol kl'udným spôsobom žit'."

Sudca voči zapisovatel'ke: „V plnom rozsahu sa pridržiavam opravného prostriedku proti rozhodnutiu KS v BA. Poukazujem na dôvody, ktoré som podrobne uviedol vo svojom písomnom podaní. Žiadam, aby súd zmenil tak, že zruši rozhodnutie MU z 1.9. MU/999/POŽ 2006 v časti o neudeleni azylu a vec mu vráti na d’alšie konanie. Poukazujem na to, že bezpečnostná situácia v krajine sa nad'alej zhořsuje."

Sudca voči žiadatel'ovi: „Koho to tam zastrelili? A kvôli čomu to bolo?“

Fakt, že žiadatel’ov príbeh ostáva väčšinou nevypočutý, analyzovala aj právna antropologička Katrijn Maryns (2006) počas komunikácie na azylových súdoch v Belgicku: „Prejav je zásadný nástroj zdôvodnenia žiadosti. Prejav žiadatel’a o azyl je však konfrontovaný s ideológiou textuality, ktorá vylučuje podstatnú kontextualizačnú prácu v interakcii a reštrukturuje výpovede do neosobných odborných kategórí spôsobmi, ktoré sú mimo žiadatel'ovej kontroly. Táto konfrontácia zapríčiňuje, že žiadatel’ov hlavný nástroj stráca svoj význam“ (Maryns 2006: 341). Na dekontextualizáciu a rekontextualizáciu reči žiadatel’ov počas byrokratických a právnych úkonov preverovania upozorn̆uje aj Gibbons (2003) a Eades (2008). Podobne som zaznamenala, že prejavy žiadatel’ov boli zostručnené, preštylizované, zhodnotené a dekontextualizované natol'ko, že žiadatel' niekedy ani nespoznal svoje autorstvo.

V tomto zmysle Wadensjö (1998) uvádza, že si rozhodovatelia nárokujú na jazykovú flexibilitu, ktorú však odopierajú tlmočníkom aj žiadatel’om. Podl'a nej prevažujúca predstava o tlmočení medzi právnikmi je tzv. „právna fikcia“, akoby tlmočníci mali byt' „odtelesnené 
mechanické prostriedky“, pričom ich výroky môžu byt' tak platné, ako keby to boli „výroky z prvej ruky“. Tlmočnícke vyjasňovanie by bolo „ohrozením právneho systému“, preto tlmočníkom nie je priznaná, ba priam zakázaná možnost' interkultúrneho mediátorstva, aj ked' sa jej prakticky nedá vyhnút' (Wadensjö 1998: 74-75).

Celkovo je pre preskriptívny prístup príznačné, že tlmočník je vnímaný ako prekladacie zariadenie, naopak pre deskriptívny prístup je tlmočník pokladaný za klúčového sprostredkovatel'a medzi žiadatel'om a inštitúciami (Gibbons 2003). Nakol'ko mnoho zamietnutí vznikne práve na základe nejasností či protirečení, by podl’a Barskeho (2000) kvalifikovaní tlmočníci mali mat' možnost' klást' vhodné doplňujúce otázky. Pre primerané tlmočenie je nedostatočné tlmočit' výroky ako také, naopak, je potrebné výroky zasadit' do širšieho socio-historického rámca (Barsky 2000: 58).

Podobne bola prejavená snaha tlmočníkovi priznat' rolu medzikultúrneho tlmočenia aj niektorými aktérmi v krajinách V4 a na Ukrajine. V tomto zmysle kvalifikovaní tlmočníci tiež uvádzali potrebu kultúrnej mediácie, ale nakol'ko ju zákon nedovol'uje, ich možnosti vysvetl'ovat' kontext bol minimalizovaný. Na druhej strane, vybraní rozhodovatelia namietali riziká udržania hraníc vplyvu tlmočníka. Predpokladám, že chceli predíst' neetickému tlmočeniu, ktoré robí nadinterpretatívnu prácu. Podl’a Wadensjö však skutočná „dialogická perspektíva pristupuje ku všetkým účastníkom komunikácie v zmysle, že robia interpretatívnu prácu“ (Wadensjö 1998: 282). Rada by som zdôraznila, že akokol'vek rozhodovatelia kontrolujú priebeh interview, v praxi nemôžeme zažit' nič iné ako interakciu, ktorá je konštituovaná prejavmi všetkých zúčastnených aktérov.

\section{Záver}

Ciel'om tohto príspevku bolo ukázat', aké prístupy sa uplatňujú v tlmočení cudzincom, ktorí prídu do styku so štátnou správou na hraniciach, na úradoch a na súdoch. Vychádzala som pritom z vlastných pozorovaní týchto interakcií od roku 2005 a z porovnávacej správy „Komunikácia s cudzincami: právne dôsledky tlmočenia. Porovnanie praktík v krajinách V4: v Pol'sku, v Mad'arsku, v Česku, na Slovensku a na Ukrajine“ z roku 2011. Pri analýze tohto materiálu som uplatnila dve epistemológie: (1) kontextuálne, opisujúce ponímanie vs. (2) formalistické, predpisujúce (Barsky 2000, Gibbons 2003), (1) orientácia na vzt’ahy vs. (2) orientácia na pravidlá (Good 2007), (1) deskriptívne vs. (2) preskriptívne interpretácie (Good 2007), (1) procesne vs. (2) zápisne orientované rozhodovanie (Philips 1998), (1) dialogizmus vs. (2) monologizmus v tlmočení (Wadensjö 1998).

V tomto zmysle sa rozhodnutia žiadatel’ov aj rozhodovatel’ov rôznia v závislosti od kultúrnych presvedčení aj od inštitucionálnej afiliácie. Podobne aj odborné práce $\mathrm{v}$ zahraničí (Barsky 2000; Berk-Seligson 2002; Eades 2010; Gibbons 2003; Good 2007; Maryns 2006; Philips 1998; Wadensjö 1998) poukazujú na ideológiu odmietania inakosti a pretrvávanie mýtov o l’udskej komunikácii. Vo viacerých európskych krajinách sa preto rozširujú pravidlá dobrej praxe pre tlmočníkov, úradníkov a sudcov. Odpoved' na potrebu všetkých aktérov ohl'adom kvalifikovaného priebehu súdneho, správneho a iného právneho konania a tlmočenia vzniká v spolupráci predstavitel’ov štátnej správy a odborníkov z rôznych vedných disciplín. 
Je pozoruhodné, ako je v oboch anglických pojmoch interpreting a interpretation, teda tlmočenie aj výklad, spoločný základ slova inter, teda medzi. Obe tieto sesterské slová obsahujú význam otvorenosti voči rôznosti výkladu. Interpretácia, ktorá je reprezentovaním významu, poslucháčovi otvára priestor medzi, na pomedzí. V tomto zmysle deskriptívna interpretácia dovol'uje opisnost'ou vysvetlit' rozdielnosti, ktoré hl'adajú medzikultúrne objasnenie: tak v tlmočení, vo vedení interview, ako aj v uplatnení práva.

\section{Literatúra}

Bargerová, Zuzana, Katarína Fajnorová a Alena Chudžíková. 2011. Stav integrácie cudzincov s doplnkovou ochranou do spoločnosti a návrhy odporúčani pre tvorcov verejných politík. Bratislava: Stimul.

Barsky, Robert F. 2000. Arguing and Jutifying. Aldershot: Ashgate.

Bázlik, Miroslav a Teodor Hrehovčík. 2013. Súdny preklad a tlmočenie. Bratislava: Iura Edition.

Berk-Seligson, Susan. 2002. The Bilingual Courtroom. Court Interpreters in the Judicial Process. Chicago: The University of Chicago Press.

Eades, Diana. 1994. „A Case of communicative clash: Aboriginal English and the legal system.“ Pp. 234-264 in J. Gibbons (ed.). Language and the Law. London: Longman.

Eades, Diana. 2008. Courtroom Talk and Neocolonial Control. Berlin: Walter de Gruyter.

Eades, Diana. 2010. Sociolinguistics and the Legal Process. Bristol: Multilingual Matters.

Gallová Kriglerová, Elena, Jana Kadlečíková a Jarmila Lajčáková. 2009. Migranti. Nový pohlad na staré problémy. Multikulturalizmus a kultúrna integrácia migrantov na Slovensku. Bratislava: Centrum pre výskum etnicity a kultúry.

Gibbons, John. 2003. Forensic Linguistics. An introduction to language in the justice system. Oxford: Blackwell Publishing.

Good, Anthony. 2007. Anthropology and Expertise in the Asylum Courts. New York: Routledge-Cavendish.

Good, Anthony. 2008. „Cultural evidence in courts of law.“ Journ of the Royal Anthropological Institute 14 (1): 47-60.

Guldanová, Zuzana et al. 2013. Kontexty súdneho prekladu a tlmočenia II. Bratislava: Univerzita Komenského.

Kadlečíková, Jana, Elena Gallová Kriglerová a Tina Gažovičová. 2011. Integrácia migrantov na lokálnej úrovni. Výskumné zistenia a odporúčania. Bratislava: Centrum pre výskum etnicity a kultúry.

Maryns, Katrijn. 2006. The Asylum Speaker: Language in the Belgian Asylum Procedure. Manchester: St. Jerome Publishing.

Philips, Susan U. 1998. Ideology in the Language of Judges. How Judges Practise law, politics, and Courtroom Control. New York: Oxford University Press.

Štefková, Marketa. 2013. Právny text v preklade. Translatologické aspekty právnej komunikácie v kombináciách málo rozširených jazykov. Bratislava: Iura Edition.

Tužinská, Helena. 2009a. „Communication in the Asylum Courts: Limits of Inquiry.“ Slovenský národopis 57 (5): 560-578.

Tužinská, Helena. 2009b. „Kultúrna citlivost'““ Pp. 79-108 in M. Mittelmannová, M. Volanská a H. Tužinská (eds.). Vybrané práva cudzincov na územi SR a kultúrna rozmanitost'. Princíp nenavrátenia, zlúčenie rodiny a kultúrna citlivost'. Bratislava: Stimul. 
Tužinská, Helena. 2010. Otázky opisu a prekladu. Využitie poznatkov antropológie a etnografie vo vedení a tlmočeni interview s cudzincami. Bratislava: Stimul.

Tužinská, Helena. 2011a. Questions of Description and Translation. Using Data from Anthropology and Ethnology in the Conduct and Interpretation of Interviews with Immigrants. Bratislava: Stimul. Cit. 8. prosince 2014 (http://stella.uniba.sk/texty/HT_questions.pdf).

Tužinská, Helena. 2011b. Komunikácia s cudzincami: právne dôsledky tlmočenia. Porovnanie praktík v krajinách V4: v Pol’sku, v Mad'arsku, v Česku, na Slovensku a na Ukrajine. Bratislava: Liga za l'udské práva. Cit. 8. prosince 2014 (https://uniba.academia.edu/HelenaTužinská/Reports).

Tužinská, Helena. 2015. „Sociolekt, migranti a tlmočenie: interakcia v štátnom sektore.“ Pp. 241-256 in J. Wachtarczyková, L. Satinská a S. Ondrejovič (eds.). Jazyk v politických, ideologických a interkultúrnych vztahoch, Sociolinguistica Slovaca 8. Bratislava: SAV.

Wadensjö, Cecilia. 1998. Interpreting as Interaction. London: Longman.

\section{Pod'akovanie}

Ďakujem za rozhovory žiadatel'om, rozhodovatel'om, tlmočníkom, ako aj za pripomienkovanie textu Zuzane Bargerovej, Zuzane Búrikovej, Táni Bužekovej, Darine Mackovej, Miroslave Mittellmannovej a anonymným recenzentom.

\section{Autorka}

Helena Tužinská prednáša na Katedre etnológie a muzeológie Filozofickej fakulty Univerzity Komenského. Spolupracuje s Ligou za l’udské práva a s Nadáciou Milana Šimečku. Zaoberá sa uplatňovaním antropologických poznatkov, interkultúrnou komunikáciou a inkluzívnym vzdelávaním.

Kontakt: helena.tuzinska@gmail.com 